\title{
Review Literature : DECISION SUPPORT SYSTEM UNTUK PENGOLAHAN KELAPA TERPADU
}

\author{
Hermiza Mardesci $^{(1)}$, Santosa ${ }^{(2)}$, Novizar Nazir ${ }^{(3)}$, Rika Ampuh Hadiguna ${ }^{(4)}$ \\ ${ }^{(1)}$ Dosen Teknologi Pangan UNISI \\ mimzaaci@yahoo.co.id \\ ${ }^{(2)}$ Dosen Teknologi Pertanian Universitas Andalas Padang \\ santosa764@yahoo.co.id \\ ${ }^{(3)}$ Dosen Teknologi Pertanian Universitas Andalas Padang \\ nazir_novizar@yahoo.com \\ (4) Dosen Teknik Industri Universitas Andalas Padang \\ hadiguna10@gmail.com
}

\begin{abstract}
Abstrak
Makalah ini bertujuan untuk melihat sejauh mana penelitian terkait sistem pendukung keputusan dan pengolahan kelapa terpadu yang telah dilakukan pada riset-riset terdahulu. Metode yang digunakan adalah dengan melakukan review jurnal-jurnal terkait pengolahan kelapa terpadu, dan sistem pendukung keputusan. Didapatkan sekitar 100 buah jurnal. Dari hasil review jurnal didapatkan gap pengetahuan yang akan diisi adalah mengaplikasikan konsep DSS untuk pengolahan kelapa terpadu, sehingga penggunaan bahan baku kelapa untuk pengolahan bisa dioptimalkan. Untuk mengoptimalkan penggunaan bahan baku dalam pengolahan kelapa terpadu, bisa dilakukan dengan bantuan Sistem Pendukung Keputusan. SPK ini bisa membantu petani kelapa dan pihak terkait untuk memutuskan pengolahan kelapa yang akan dipilih sehingga penggunaan bahan baku bisa optimal.
\end{abstract}

Keywords : Decisions Support System (DSS), Coconut Process

\section{PENDAHULUAN}

Dalam rangka mensukseskan program pemerintah terkait pengolahan kelapa, khususnya Departemen Perindustrian yang menetapkan sasaran jangka panjang, salah satunya adalah berkembangnya industri pengolahan kelapa secara terpadu di Indonesia, maka para petani dan industri kelapa diharapkan bisa menghasilkan banyak produk dari pengolahan kelapa. Namun industri pengolahan kelapa saat ini masih didominasi oleh produk setengah jadi berupa kopra dan coconut crude oil (CCO). Apalagi dikalangan petani kelapa, mereka cenderung memilih menjual kelapa bulat dibandingkan dengan mengolahnya terlebih dahulu.

Upaya pemerintah untuk menggalakkan pengolahan kelapa terpadu sudah dilakukan dengan memberikan bantuan alat pengolahan kelapa terpadu kepada kelompok tani di sentra-sentra penghasil kelapa, seperti di Provinsi Riau, khususnya Kabupaten Indragiri Hilir. Kenyataannya di lapangan, kelompok tani masih berpikiran pragmatis dengan tetap mempertahankan tradisi, yakni menjual kelapa bulat tanpa harus mengolah 
terlebih dahulu. Hal tersebut terjadi karena kurangnya pengetahuan dan alat bantu dalam mengambil keputusan terkait pengolahan kelapa. Oleh karena itu diperlukan suatu alat yang dapat memudahkan untuk menghitung dan mengendalikan penggunaan bahan baku dan produktivitas, sehingga pengolahan kelapa terpadu menjadi pilihan utama dibandingkan dengan menjual kelapa bulat.

Tanaman kelapa disebut juga tanaman serbaguna, karena dari akar sampai ke daun kelapa bermanfaat, demikian juga dengan buahnya. Buah adalah bagian utama dari tanaman kelapa yang berperan sebagai bahan baku industri. Buah kelapa terdiri dari beberapa komponen yaitu sabut kelapa, tempurung kelapa, daging buah kelapa dan air kelapa. Daging buah adalah komponen utama yang dapat diolah menjadi berbagai produk bernilai ekonomi tinggi. Sedangkan air, tempurung, dan sabut sebagai hasil samping (by product) dari buah kelapa juga dapat diolah menjadi berbagai produk yang nilai ekonominya tidak kalah dengan daging buah (Lay dan Pasang, 2003; Maurits, 2003; Nur et al., 2003). Berbagai produk yang dapat dihasilkan dari buah kelapa dapat dilihat pada Gambar 1.

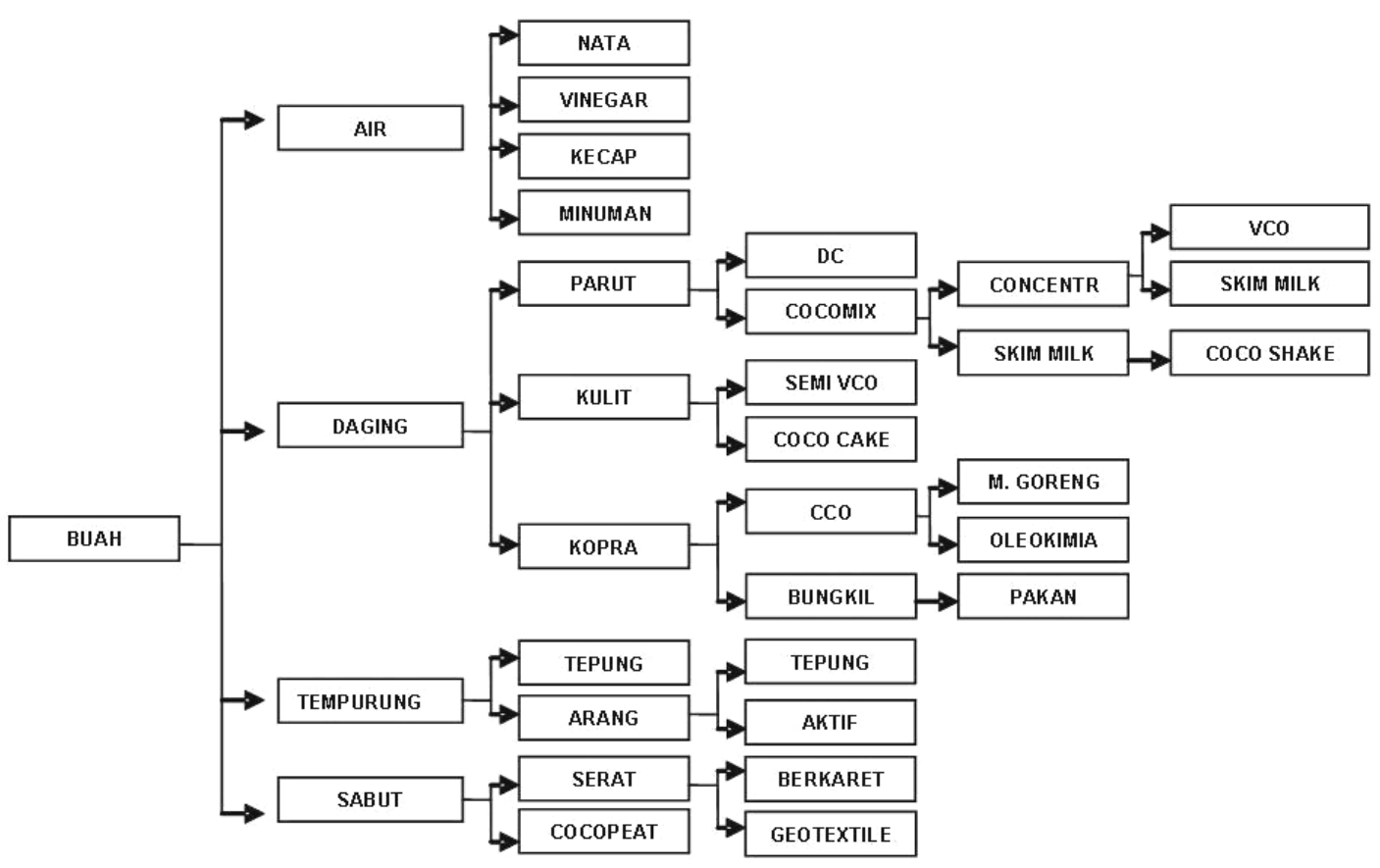

Gambar 1. Berbagai Produk yang Dihasilkan dari Buah Kelapa

Dalam pengolahan kelapa terpadu, diperlukan dukungan beberapa aspek terkait teknologi industri pertanian seperti manusia, bahan, peralatan, informasi, dan energi. Aspek manusia yang mendukung adalah pendidikan, pelatihan dan motivasi yang dimiliki petani kelapa dalam melaksanakan pengolahan kelapa terpadu. Aspek bahan adalah bahan baku kelapa dan bahan pendukung lainnya yang diperlukan dalam pengolahan kelapa. Aspek peralatan adalah segala alat bantu yang berupa alat dan mesin yang digunakan 
dalam pengolahan kelapa terpadu. Aspek informasi adalah segala informasi atau pengetahuan yang bisa digunakan dalam pengolahan kelapa terpadu. Sedangkan aspek energi adalah segala energi dan daya yang dibutuhkan untuk proses pengolahan kelapa terpadu.

Aspek informasi yang dibutuhkan oleh petani kelapa dalam pengolahan kelapa terpadu tidak hanya sebatas pengetahuan tentang cara pengolahan kelapa, tetapi juga tentang cara mengatur penggunaan bahan baku kelapa, agar bahan baku yang digunakan bisa optimal. Jika bahan baku sudah optimal, efisiensi bisa meningkat karena limbah yang dihasilkan sedikit.

\section{REVIEW LITERATUR}

\section{Tujuan}

Tujuan dari mencari jurnal atau literatur ini adalah untuk menemukan hasil riset-riset terdahulu terkait pengolahan kelapa terpadu dan sistem pendukung keputusan, sehingga bisa ditemukan gap pengetahuan yang akan diisi dengan riset yang akan dilakukan.

\section{Metode Pencarian}

Jurnal yang dicari adalah dari tahun 1992 sampai 2014, melalui Directory of Open Access Journals (DOAJ), Proquest, ScienceDirect, dan beberapa jurnal lokal lainnya, dengan menggunakan kata kunci; Decision Support System (DSS), Sistem Pendukung Keputusan, Pengolahan Kelapa Terpadu, dan Coconut Process. Riset terkait pengolahan kelapa didapatkan sekitar 16 buah laporan penelitian, sedangkan yang terkait DSS sekitar 95 buah laporan hasil penelitian.

\section{Hasil Pencarian}

\section{Pengolahan Kelapa Terpadu}

Penelitian tentang kelapa telah banyak dilakukan, mulai dari proses pengolahan sampai dengan perhitungan ketersediaan bahan baku. Puspitawaty (1992), E. Assidjo, et al. (2008), dan Wardah, et al. (2012) membahas tentang model pengendalian bahan baku kelapa untuk industri kelapa parut kering. Model yang dihasilkan adalah model persediaan dengan permintaan yang stokastik, serta model persediaan yang menggunakan model Economic Order Quantity Pengembangan (EOQp) dan pengali Lagrange yang memasukan parameter umur simpan dan kapasitas gudang penyimpanan sehingga mendapatkan hasil yang lebih optimal sedangkan dalam pemilihan pemasok digunakan metode Analytical Hierarchy Process (AHP). Model ini hanya bisa digunakan untuk industri kelapa parut kering, padahal pengolahan kelapa terpadu tidak hanya menghasilkan satu macam produk tersebut.

Model persediaan bahan baku lainnya dibahas oleh Ramli dan Nurahmawati (2014). Model yang dikembangkan adalah untuk model persediaan bahan baku untuk pengolahan nata de coco. Sedangkan model persediaan bahan baku untuk beberapa produk hasil pengolahan kelapa belum ada ditemukan.

Pentingnya pengolahan kelapa terpadu dijelaskan dalam penelitian Ismandari (2011), Bambang (2009), Romano (2013), Rahman, Nendi F (2011), Auwdinata, et al. (2014). Secara umum dijelaskan bahwa pengolahan kelapa terpadu penting dilakukan karena potensi kelapa di Indonesia cukup tinggi, dan pemanfaatan kelapa belum optimal. Padahal kelapa bisa diolah menjadi 
berbagai produk olahan yang beraneka ragam, seperti pengolahan gula merah (Muchaymien, et al., 2014), pengolahan air kelapa yang bisa dikombinasikan dengan jambu biji (Carvalho, et al., 2005), dan Pereira, et al. (2013) juga meneliti pengolahan air kelapa dengan mengoptimalkan penggunaan Kalium Sorbat dan Natrium Metabisulfit.

Selain itu, produk sampingan seperti tempurung dan serat sabut kelapa juga bisa dimanfaatkan. Dema da Silva, et al. (2013) mempelajari sifat fisik dan kimia dari serat sabut kelapa untk dimanfaatkan sebagai adsorbsi logam berat. Dengan banyaknya olahan kelapa yang bisa dihasilkan, daya saing kelapa di pasaran cukup menjanjikan. Daya saing komoditas kelapa sudah dipelajari Setiawan, et al. (2014) yang menyatakan bahwa komoditas kelapa memiliki daya saing yang tinggi di pasaran.

Dari hasil pencarian tersebut,
belum terlihat bagaimana cara
mengoptimalkan penggunaan bahan baku dalam pengolahan kelapa terpadu. Padahal, dengan banyak produk olahan yang bisa dihasilkan dari kelapa, perlu suatu manajemen atau pengaturan tentang produk apa yang harus diprioritaskan, dan bagaiamana cara pengolahan yang efisien, sehingga penggunaan bahan baku bisa optimal. Jika penggunaan bahan baku sudah optimal, maka limbah yang dihasilkan bisa dikurangi.

\section{Sistem Pendukung Keputusan}

Definisi awal Sistem Pendukung Keputusan (SPK) adalah suatu sistem yang ditujukan untuk mendukung manajemen pengambilan keputusan. Sistem berbasis model yang terdiri dari prosedur-prosedur dalam pemrosesan data dan pertimbangannya untuk membantu user dalam mengambil keputusan. Agar berhasil mencapai tujuannya maka sistem tersebut harus: sederhana, kuat, mudah untuk dikontrol, mudah beradaptasi, lengkap pada hal-hal penting, dan mudah untuk digunakan. Tiga buah tujuan SPK yang harus dicapai adalah: membantu user membuat keputusan, mendukung penilaian user bukan mencoba untuk menggantikannya, meningkatkan efektifitas pengambilan keputusan user.

Pengembangan suatu SPK sering menghadapi kesulitan akibat adanya karakteristik sistem yang tidak pasti, kompleks, dinamis, serta keterbatasan sumber daya. Pada sisi lain, SPK memberikan keuntungan sebagai berikut (Turban \& Aronson, 2001):

1. Memiliki kemampuan dalam membantu menyelesaikan masalah yang kompleks

2. Memiliki tanggapan yang cepat terhadap situasi yang diharapkan karena pengaruh perubahan keadaan. SPK secara teliti memberikan beberapa analisa dalam waktu yang singkat. Perubahan yang mendasar dapat dievaluasi dengan cepat dan efisien.

3. Menghemat biaya, penggunaan aplikasi SPK secara rutin dapat menghemat biaya akibat pengambilan keputusan yang keliru. Keputusan obyektif yang dihasilkan oleh SPK bersifat lebih konsisten dan obyektif dibandingkan keputusan intuitif.

Dilihat dari pengertian dan keuntungan dari sebuah aplikasi SPK tersebut diharapkan bisa dimanfaatkan untuk membantu user dalam mengambil keputusan terkait penggunaan bahan baku untuk pengolahan kelapa terpadu.

Penelitian tentang Sistem Pendukung Keputusan sudah banyak 
dilakukan. Aplikasi SPK bisa mencakup semua aspek, seperti kesahatan, pertanian, teknik, ekonomi, informatika, teknologi industri pertanian dan lain sebagainya.

Di bidang kesehatan, penelitian tentang sistem pendukung keputusan cukup banyak dilakukan. Sistem pendukung keputusan yang dibuat digunakan untuk membantu dokter dalam mengambil keputusan. Pielmeier, Ulrike et al. (2012), dan Çomak, Emre \& Ahmet Arslan (2012) berhasil membuat suatu sistem pendukung keputusan yang bisa digunakan oleh dokter dalam mengambil keputusan terkait cara mengurangi hyperglikemia, dan cara mengevaluasi gangguan katup jantung. Selain itu, Obropta, Christopher et al. (2008) telah merancang suatu sistem pendukung keputusan terkait masalah lingkungan. Terbukti sistem pendukung keputusan yang dirancang cukup membantu pengambil kebijakan dalam menyelesaikan permasalahan lingkungan. Delavarian, Mona et al. (2012), dan Brunette, Mary et al. (2011) merancang sistem pendukung keputusan masing-masing untuk membedakan jenis gangguan perilaku anak, dan motivasi untuk berhenti merokok bagi pecandu rokok. Tebukti dari sistem pendukung keputusan yang dirancang bisa membantu pengambil kebijakan dalam mengambil keputusan.

Beberapa rancangan sistem pendukung lainnya di bidang medis lainnya cukup membantu pekerja medis dalam mengambil keputusan, mulai dari mendiagnosa penyakit sampai untuk pengembangan pengetahuan di bidang kesehatan. Blazewicz, Jacek et al. (2012) merancang sebuah sistem pendukung keputusan untuk proses pengembangan vaksin. Wilson, Carlene et al. (2010), Traffon, Jodie et al. (2010), Crouwels et al. (2001), Obi J. C and Imainuan (2011), Ravindran, Sindhu et al. (2015), serta Turgoklu, Ibrahim (2002) merancang sistem pendukung keputusan yang bisa membantu petugas medis untuk diagnosa penyakit seperti jantung, alzheimer, skrining kanker, kesehatan janin, dan untuk terapi nyeri klinis lainnya. Sistem pendukung keputusan yang dihasilkan terbukti mampu membantu petugas medis dalam mengambil kebijakan terkait diagnosa penyakit.

Di bidang pertanian, sistem pendukung keputusan ini juga cukup banyak dirancang untuk membantu para petani dan pihak yang berkepentingan dalam bidang pertanian dalam mengambil keputusan. Simanungkalit, et al. (2013) merancang sebuah sistem pendukung keputusan untuk peramalan harga komoditas tanaman pangan. Sistem pendukung keputusan yang dirancang menggunakan jaringan saraf tiruan, dan terbukti mampu memberikan ramalan terhadap harga komoditas tanaman pangan. Erniati, et al. (2013) merancang sistem pendukung keputusan untuk penetapan indeks ketahanan pangan. Sistem pendukung keputusan yang dibangun untuk menetapkan indeks ketahanan pangan di tingkat rumah tangga dan wilayah. yang dapat digunakan sebagai sistem informasi berbasis komputer untuk mengolah dan menyajikan data dengan lebih baik sebagai bahan acuan bagi para pengambil kebijakan terkait masalah ketahanan pangan.

Arkeman, Yandra, dan R.A. Dharma (2012) telah melakukan penelitian dengan Sistem Penunjang Keputusan Cerdas untuk Mengelola Rantai Pasokan pada Agroindustri Hortikultura. Sistem penunjang keputusan yang dihasilkan dapat 
membantu pengguna untuk mengelola rantai pasokan pada agroindustri hortikultura selama rentang waktu satu tahun ke depan. Susilawati (2012) juga merancang sistem pendukung keputusan di bidang pertanian dengan judul Rainwater Management Model Development for Agriculture in the Savu Island Semi-Arid Region. Sistem pendukung keputusan yang dirancang cukup membantu untuk pengendalian air hujan untuk pertanian di wilayah semi kering. Sementara itu, Wenting, et al. (2013) merancang sistem pendukung keputusan untuk diagnosis kebutuhan air tanaman. Santosa, et al. (2006) merancang sistem pendukung keputusan untuk produksi buah-buahan unggul nasional. dihasilkan basis data kesesuaian lahan, dan sistem informasi berbasis komputer untuk kegiatan produksi buah, yaitu salak (kultivar pondoh), mangga (kultivar arumanis, manalagi, golek, dan gedong).

Massinai et al. (2009) juga merancang sistem penunjang keputusan dalam bidang pertanian. Penelitiannya yang berjudul Sistem Pengambilan Keputusan untuk Pengembangan Usahatani Terpadu di Lahan Pasang Surut, bertujuan untuk mendesain sistem informasi untuk mendukung pengambilan keputusan dalam pengelolaan sistem usahatani secara terpadu di wilayah lahan pasang surut, dan menentukan tingkat kelayakan sistem usahatani terpadu berdasarkan analisis ekonomi di wilayah lahan pasang surut tipe $\mathrm{B}$ dan $\mathrm{C}$ Desa Gandang, Kalimantan Tengah. Pada tahun 2010, Scarpari dan EGF de Beauclair juga merancang sebuah sistem penunjang keputusan untuk meengoptimalkan perncaanaan pada pertanian tebu. Sistem dibangun dengan bantuan model linear programming. Kemudian Multsch et al., (2013) juga melakukan penelitian di bidang pertanian yang berjudul A Site-Specific Agricultural Water Requirement and Footprint Estimator (Spare:Water 1.0) for Irrigation Agriculture.

Shanshan Lin, et al. (2008) merancang sebuah sistem pakar untuk manajemen resiko tingkat petani dalam menggunakan irigasi. Sedangkan ShihHsun Chang (2014) merancang sebuah sistem pendukung keputusan untuk membantu pengguna dalam menentukan klasifikasi padi. Nan Lin, et al. (2013) mengembangkan sebuah sistem pendukung keputusan untuk pengembangan produksi jagung. Valente, Domingos (2011) merancang sebuah sistem pendukung keputusan untuk penentuan biaya dalam operasi fasilitas penyimpanan biji-bijian.

Sistem pendukung keputusan di bidang pertanian tidak hanya terbatas pada bidang budidaya dan produksi, tetapi ada juga yang terkait dengan cara penanggulangan hama dan penyakit (Uchoa, et al., 2010), ketersediaan mesin pertanian (Wang, Ying et al., 2014), dan juga distribusi (Zhi-Hua Hu, et al., 2010) serta investasi (Aziz Galvão da Silva Júnior, 2015). Selain itu, Centini, Marco et al. (2010), dan Sharma, A.K., et al. (2011) juga merancang sistem pendukung keputusan yang terkait dengan bidang pertanian. Sistem pendukung keputusan yang dirancang terbukti cukup membantu pengguna dalam mengambil keputusan untuk menyelesaikan persoalan masingmasing.

Sistem penunjang keputusan juga bisa digunakan dalam bidang pendidikan, seperti untuk membantu memilih konsentarasi jurusan. Harison (2013) telah merancang sistem penunjang keputusan untuk menentukan konsentrasi jurusan teknik mesin di 
UNP Padang. Begitu juga dengan Pratiwi et al. (2014) juga melakukan penelitian dengan judul Decision Support System to Majoring High School Student Using Simple Additive Weighting Method.

Meilani, D., dan Amirulfiras, R. (2015) telah merancang sebuah sistem penunjang keputusan yang berjudul Perancangan Sistem Penunjang Keputusan Investasi Daerah Berbasis Webgis di Provinsi Sumatera Barat. Perancangan Sistem Penujang Keputusan (SPK) tersebut dilakukan dalam upaya mendukung promosi investasi daerah dengan menyediakan sebuah aplikasi yang dapat membantu memberikan penilaian terhadap kelayakan sebuah investasi yang dilihat dari sisi ekonomi finansialnya. Penelitian ini di lakukan di BKPMP (Badan Kordinasi Penanaman Modal Provinsi Sumatera Barat) sebagai pihak berwenang dalam menentukan perizinan dan pengawasan investasi provinsi. Sistem penunjang keputusan yang terkait investasi juga telah dirancang oleh Hadisenjaya, H. (1995) dalam skripsinya yang berjudul Sistem Penunjang Keputusan untuk Investasi pada Industri Tepung Ikan.

Di bidang Teknologi Industri Pertanian, sistem pendukung keputusan juga cukup banyak digunakan. Beberapa hasil penelitian menunjukkan bahwa sistem pendukung keputusan yang dirancang cukup membantu pengguna dalam mengambil keputusan untuk menyelesaikan persoalan di bidang teknologi industri pertanian. Munhoza, José Renato and Reinaldo Morabitob (2013), Fibrian, D. Chandra, et al. (2013), Hadiguna, Rika A. (2010), merancang sistem pendukung keputusan yang masing-masing bertujuan untuk membantu pengguna dalam mengambil keputusan atau menentukan kebijakan terkait teknologi industri pertanian.

Turban (1990) menyatakan bahwa sistem penunjang keputusan adalah sistem komputerisasi informasi yang menggunakan aturan-aturan keputusan dan model-model. Basis model diakomodasikan dengan basis data dan pandangan pribadi pengambil keputusan yang menuntun kepada keputusan yang spesifik dalam pemecahan masalah-masalah yang tidak dapat diselesaikan hanya dengan model optimasi ilmu manajemen. Masalah keputusan yang terstruktur memiliki prosedur untuk mendapatkan solusi yang terbaik atau relatif cukup baik, sedangkan dalam masalah keputusan yang bersifat tidak terstruktur, intuisi manusiamasih menjadi dasar pengambilan keputusan. Masalah yang bersifat semi structural berada di antara kedua masalah tersebut, melibatkan prosedur-prosedur penyelesaian masalah bahan baku dan pendapat atau pertimbangan pribadi.

\section{KESIMPULAN}

Pengolahan kelapa terpadu merupakan pengolahan kelapa yang dilakukan dengan memanfaatkan semua bagian kelapa, sehingga produk yang dihasilkan bervariasi dan bermacammacam. Jika dikaitkan dengan teknologi industri pertanian, pengolahan kelapa terpadu ini memiliki beberapa permasalahan, seperti sumber daya manusia, alat dan bahan, energi, dan juga informasi.

Selain informasi, permasalahan tersebut bisa diatasi melalui programprogram pemerintah dengan memberikan pelatihan untuk kelompok tani kelapa, memberikan bantuan alat pengolahan kelapa terpadu, serta memberikan pendampingan untuk petani kelapa dari 
instansi-instansi terkait. Sedangkan permasalahan informasi perlu penyelesaian yang lebih banyak, karena informasi yang dimaksud, tidak hanya informasi tentang cara pengolahan kelapa terpadu, tetapi juga bagaimana mengoptimalkan penggunaan bahan baku dan peralatan, sehingga pengolahan kelapa bisa efektif dan efisien.

Dilihat dari riset-riset terdahulu tentang pengolahan kelapa, sudah ada beberapa hasil penelitian yang membahas tentang ketersediaan bahan baku, tetapi terbatas pada satu produk, seperti ketersediaan bahan baku untuk kelapa parut kering, atau ketersediaan bahan baku untuk nata de coco, dan lainlain. Padahal, pengolahan kelapa terpadu tidak terbatas pada satu atau dua produk. Selain itu, penelitian tersebut dihasilkan dalam bentuk model matematika, sehingga sulit untuk disosialisasikan ke masayarakat. Untuk itu diperlukan suatu sistem pendukung keputusan yang terkomputerisasi, sehingga lebih mudah digunakan dan dimanfaatkan bagi pengambil keputusan.

Dalam pengolahan kelapa terpadu ini, para pengambil keputusan dihadapkan pada penentuan bagaimana keputusan-keputusan yang rasional harus diambil dan menentukan pilihan yang tepat dan akurat secara cepat. Sistem pendukung keputusan yang dikembangkan akan membantu proses pengambilan keputusan mengenai pengendalian bahan baku dan peralatan. Sistem ini diharapkan mampu menganalisa faktor-faktor yang berpengaruh dalam pengendalian bahan baku serta memberikan informasi yang berkaitan dengan pengolahan kelapa terpadu yang dibutuhkan oleh pengguna.

\section{DAFTAR PUSTAKA}

Arifah, Eva, et al. 2014. Sistem Penunjang Keputusan Mutu Biodiesel Berbasis Web Jurnal Teknologi Industri Pertanian Vol. 21 (2), 118-130. Institut Pertanian Bogor. Bogor.

Arkeman, Yandra, dan R.A. Dharma. 2012. Sistem Penunjang Keputusan Cerdas untuk Mengelola Rantai Pasokan pada Agroindustri Hortikultura. Jurnal Teknologi Industri Pertanian. Vol. 19(3), 152-163. Insitut Pertanian Bogor. Bogor.

Asabere, Nana Yaw and Nana Kwame Gyamfi. 2013. AIDSS-HR: An Automated Intelligent Decision Support System for Enhancing the Performance of Employees. IJCSN International Journal of Computer Science and Network, Volume 2, Issue 4, August 2013.

Auwdinata, A. Christmas et al. 2013. Perancangan Company Profile Perusahaan Pengolah Kelapa UD. Kelapa Terpadu. Skripsi. Universitas Kristen Petra. Surabaya.

Aziz Galvão da Silva Júnior. 2015. Biodiesel FAO: An Integrated Decision Support System for Investment Analysis in the Biodiesel Production Chain. International Journal Food System Dynamics 6 (2), 2015, 110-116.

Bani, Mohammad Shahnor, Zulkifli Abdul Rashid and $\mathrm{Ku}$ Halim $\mathrm{Ku}$ Hamid . 2011. Implementation of Decision Support System for Scheduled Waste Management

Malaysia. Journal of Appli Sciences 11 (13): 2358-2363, 2011.

Barthel, Daniel et al. 2007. A Decision Support System for Protein 
(Structure) Comparison,

Knowledge, Similarity and

Information. $\quad$ BMC

Bioinformatics 2007, 8:416

doi:10.1186/1471-2105-8-416

Blazewicz, Jacek. 2012. Decision

Support System for Novel Genetic

Vaccine Development Process.

BMC Bioinformatics 2012, 13:91.

Bountris, Panagiotis et al. 2014. An Intelligent Clinical Decision Support System for PatientSpecific Predictions to Improve Cervical Intraepithelial Neoplasia Detection. Hindawi Publishing Corporation BioMed Research International Volume 2014, Article ID 341483, 20 pages.

Cortes, Ulian Andres Zapata et al. 2012. Expertchoice@ Decision Support System Implementation for Vehicle Selection in A Colombian Shipyard. Dyna, year 79, Nro. 173, pp. 53-60. Medellin, june, 2012. ISSN 0012-7353.

Crauwels, A.P.P. 2001. A Concept for a Decision Support System Based on Practical Experiences from A National Disease Emergency The Dutch Experience. Acta vet. scand. 2001, Suppl. 94, 61-69.

Erniati, et al. 2013. Penyusunan Sistem

Pendukung Keputusan untuk Penetapan Indeks Ketahanan Pangan di Tingkat Rumah Tangga dan Wilayah. Jurnal AGRITECH, Vol. 33, No. 4. Universitas Gajah Mada. Yogyakarta.

Fiannaca, Antonino et al. 2013. A Knowledge-Based Decision Support System in Bioinformatics: An Application to Protein Complex Extraction.
BMC Bioinformatics 2013, 14(Suppl 1):S5

Fibrian, D.Chandra, et al. 2013. Sistem

Penunjang Keputusan untuk Optimalisasi Pemanfaatan Limbah Padat Kelapa Sawit. Jurnal Teknologi Industri Pertanian. Vol. 20 (2), 130-142. Institut Pertanian Bogor. Bogor.

Gabriel, et al. 2013. Perencanaan Strategi Pengembangan Industri Rumah Tangga Gula Kelapa. Skripsi. Universitas Brawijaya. Malang.

Hadiguna, Rika A. 2010. Perancangan Sistem Penunjang Keputusan Rantai Pasok dan Penilaian Risiko Mutu pada Agroindustri Minyak Sawit Kasar. Disertasi. Institut Pertanian Bogor. Bogor.

Han, Wenting et al. 2013. A Support System for Crop Water Requirement Diagnosis and Irrigation Decision Making. Information Technology Journal 12 (8): 1555-1562.

Handojo, Andreas, et al. 2003. Pembuatan Aplikasi Sistem Pendukung Keputusan untuk Proses Kenaikan Jabatan dan Perencanaan Karir pada PT. X. Jurnal Informatika Vol. 4, No. 2, 98 - 106. Universitas Kristen Petra.

Ismandari, Titik. 2011. Strategi Pencegahan Alih Fungsi Lahan Melalui Penerapan Modernisasi Budidaya dan Pengolahan Kelapa Terpadu di Wilayah Perbatasan Utara Kalimantan TimurMalaysia. Prosiding Seminar Nasional Budidaya Pertanian | Urgensi dan Strategi Pengendalian Alih Fungsi Lahan Pertanian. Bengkulu.

Khairani, Caya, dan Y. P. Rahardjo. 2007. Pengkajian Sistem 
Agroindustri Kelapa Terpadu Skala Rumah Tangga Di Kabupaten Donggala. Badan Penelitian dan Pengembangan Pertanian. Sulawesi Tengah.

Klintong, Noppakorn et al. 2012. Decision Support System using Artificial Neural Network for Managing Product Innovation. IJCSI International Journal of Computer Science Issues, Vol. 9, Issue 2, No 2, March 2012.

Lay, A. dan P. M. Pasang. 2003. Alat Penyerat Sabut Kelapa Tipe Balitka. Kelembagaan Perkelapaan di Era Otanomi Daerah. Prosiding Konferensi Nasional Kelapa V. Tembilahan 22 - 24 Oktoner 2002. Pp.154 159.

Lentini, Marco et al. 2010. A Decision Support System for Land Allocation Under Multiple Objectives in Public Production Forests in the Brazilian Amazon. Hindawi Publishing Corporation International Journal of Forestry Research Volume 2010, Article ID 985364, 10 pages.

Marimin, et al. 2012. Keragaan Kinerja dan Sistem Penunjang Keputusan Pengendalian Proses Produksi Gula Kristal di PT. Rajawali II Unit Pabrik Gula Jati TujuhMajalengka. Jurnal Teknologi Industri Vol. 19(3), 170-181. Institut Pertanian Bogor. Bogor.

Maurits, S. 2003. Pemanfaatan Serat Sabut Kelapa Berkaret Menjadi Jok Kursi. Kelembagaan Perkelapaan di Era Otanomi Daerah. Prosiding Konferensi Nasional Kelapa V. Tembilahan 22 - 24 Oktoner 2002. Pp. 139 145.

Miljanović, Igor \& Slobodan Vujić. 2008. Fuzzy Model of the
Computer Integrated Decision Support and Management System in Mineral Processing. Yugoslav Journal of Operations Research Vol 18 (2008), Number 2, 253259.

Nan Lin, et al. 2013. Research on Development of Corn Production Decision Support System. TELKOMNIKA, Vol. 11, No. 7, pp. 3798-3808.

Nur, I.I, Kardiyono, Umar, dan A. Aris. 2003. Pemanfaatan Limbah Debu Sabut Kelapa dalam Usahatani Padi Pasang Surut. Kelembagaan Perkelapaan di Era Otanomi Daerah. Prosiding Konferensi Nasional Kelapa V. Tembilahan 22 - 24 Oktober 2002. Pp.160 165.

Obi J.C1. and Imainvan A.A. 2011. Decision Support System for the Intelligient Identification of Alzheimer Using Neuro Fuzzy Logic. International Journal on Soft Computing ( IJSC ), Vol.2, No.2, May 2011.

Prasad, J. R., R. S. Prasad, and U. V. Kulkarni. 2008. A Decision Support System for Agriculture Using Natural Language Processing (ADSS). Proceedings of the International MultiConference of Engineers and Computer Scientists 2008 Vol I. IMECS 2008, 19-21 March, 2008, Hong Kong.

Puspitawaty, Tety. 1992. Model Simulasi Pengendalian Persediaan Bahan Baku untuk Industri Kelapa Parut Kering. Skripsi. Institut Pertanian Bogor

Rahman, Fatkhur., dan Nendi. 2011. Dampak Program Pengembangan dan Pengolahan Kelapa Terpadu Terhadap Produktivitas dan Efisiensi Penggunaan Faktor 
Faktor Produksi di Kecamatan Jatinegara Kabupaten Tegal. Skipsi. Jurusan Ekonomi Pembangunan. Fakultas Ekonomi. Universitas Negeri Semarang.

Ramli dan E. Nurahmawati. 2014. Aplikasi Metode EOQ pada Pengendalian Bahan Baku Nata De Coco "Primaiska" Desa Sindanglaka Kecamatan Karangtengah Kabupaten Cianjur. Jurnal Agroscience Volume $7 . \quad$ Universitas Suryakencana. Cianjur.

Ravindran, Sindhu et al. 2015. A Novel Clinical Decision Support System Using Improved Adaptive Genetic Algorithm for the Assessment of Fetal Well-Being. Hindawi Publishing Corporation Computational and Mathematical Methods in Medicine Volume 2015, Article ID 283532, 11 pages.

Rigopoulos, George et al. 2008. Decision Support System for Supervised Assignment in Banking Decision. Journal of Applied Sciences 8 (3): 443-452.

Romano. 2013. Potensi Produksi dan Kinerja Investasi Industri Pengolahan Kelapa Terpadu di Provinsi Aceh. Jurnal Agrisep Vol (14) No.1. Universitas Syiah Kuala, Banda Aceh.

Sandeep K., and K. Rakesh. 2011. CLIPS Based Decision Support System for Water Distribution Networks. Drink. Water Eng. Sci., 4, 37-50, 2011.

Santosa et al. 2006. Desain Sistem Penunjang Keputusan untuk Produksi Buah-Buahan Unggulan Nasional. Jurnal Agritech, Vol.26. Universitas Gajah Mada. Yogyakarta.
Scarpari, M. Salles, and G.F. de Beauclair. 2010. Optimized Agricultural Planning of Sugarcane Using Linear Programming. Revista Investigacion Operacional Vol. 31,No 2, 126-132.

Setiaji, A.H. Bambang. 2009. Manfaat Kimia Terapan pada Pengolahan Kelapa Terpadu dalam Pengembangan Industri Kecil. Pidato Pengukuhan Jabatan Guru Besar UGM. Yogyakarta

Setiaji, A.H. Bambang. 2011. Pengembangan Pengolahan Kelapa Terpadu untuk Industri Kecil di Pedesaan. Buletin Teknologi Pascapanen Pertanian. Vol 7 (2) Hal; 56-64. Yogyakarta

Setiawan, Krisna et al. 2014. Analisis Daya Saing Komoditas Kelapa di Kabupaten Kupang. Jurnal AGRITECH, Vol. 34, No. 1. Universitas Gajah Mada. Yogyakarta.

Sharma, A.K., et al. 2011. Web-enabled Decision Support System on Most Probable Producing Ability and A Searchable Database on Herd Strength for Livestock Farm Management. International Journal on Computer Science and Engineering (IJCSE) Vol. 3 No. 11 November 2011.

Shih-Hsun Chang. 2014. A Novel Approach to Developing a Supervised Spatial Decision Support System for Image Classification: A Study of Paddy Rice Investigation. Hindawi Publishing Corporation. Mathematical Problems in Engineering Volume 2014, Article ID 804548, 11 pages.

Simanungkalit, et al. 2013. Sistem Pendukung Keputusan Berbasis Jaringan Saraf Tiruan untuk 
Peramalan Harga Komoditas Tanaman Pangan. Jurnal AGRITECH, Vol. 33, No. 1. Universitas Gajah Mada. Yogyakarta.

Songsangyos, Pradit. 2014. The Decision

Support System for Hierarchical Portfolio Management. International Journal of Information and Education Technology, Vol. 4, No. 4, August 2014.

Susilawati, C.L. 2012. Rainwater Management Model Development for Agriculture in the Savu Island Semi-Arid Region. Civil Engineering Dimension, Vol. 14, No. 1, 36-41.

Trafton, Jodie A, et al. 2010. Designing An Automated Clinical Decision Support System to Match Clinical Practice Guidelines for Opioid Therapy for Chronic Pain. Implementation Science 2010, 5:26.

Turban, E. 1990. Decision Support and Expert System. Macmillan Pubishing Company, New York.

Turban, Efrain dan Aronson, Jay. 2001. Decision Support System and Intelligent System. Prentice Hall. New Jersey.

Türkoğlu, İbrahim, Ahmet Arslan, Erdoğan İlkay. 2002. A Decision Support System for The Diagnosis of Heart Valve Diseases. Cilt, 2.Sa (Temmuz 2002).

Uchôa, Cleilson do Nascimento et al. 2010. Desenvolvimento de Um Sistema de Apoio À Decisão Para A Diagnose de Doenças, Pragas E Distúrbios Abióticos dos Citros. Summa Phytopathol., Botucatu, v. 36, n. 2, p. 155-157, 2010.
Valente, Domingos S. M. 2011. A Decision Support System for Cost Determination In Grain Storage Facility Operations. Eng. Agríc., Jaboticabal, v.31, n.4, p.735-744, jul./ago. 2011.

Wang, Ying, Fen fen Yang, and Zhuolin Yan. 2014. Design and Development of Decision Support System for Equipping Farm Machines. Journal of Networks, Vol. 9, No. 6, June 2014.

Wardah, Siti et al. 2012. Rancang Bangun Model Persediaan dan Pemilihan Pemasok Bahan Baku Kelapa Parut Kering di PT. X. Jurnal Teknik Industri ISSN: 1411-6340. Universitas Trisakti. Jakarta.

Wardah, Siti. 2013. Model Pemilihan Pemasok Bahan Baku Kelapa Parut Kering Dengan Metode AHP (Studi Kasus PT. Kokonako Indonesia). Jurnal Optimasi Sistem Industri, Vol. 12 No. 2:352-357. Universitas Andalas. Padang.

Wibowo, A. Ari. 2006. Sistem Penunjang Keputusan Pengembangan Industri Komoditas Pertanian di Kawasan Agropolitan. Skripsi. Institut Pertanian Bogor.

Wilson, Carlene J, et al. 2010. Protocol for Population Testing of An Internetbased Personalised Decision Support System for Colorectal Cancer Screening. BMC Medical Informatics and Decision Making 2010, 10:50.

Yurtkuran, Alkin, Mustafa Tok and Erdal Emel. 2013. A Clinical Decision Support System for Femoral Peripheral Arterial Disease Treatment. Hindawi Publishing Corporation Computational and Mathematical 
Methods in Medicine. Volume 2013, Article ID 898041, 9 pages.

Yusuf, Muchaymien. 2014. Penyusunan

Draft Standard Operating Procedure (SOP) Pembuatan Gula Merah Kelapa. Jurnal Teknologi Industri dan Hasil Pertanian Volume 19 No.2, Juli
2014. Universitas Lampung. Lampung.

Zhi-Hua Hu, Bin Yang, You-Fang Huang. 2010. A Decision Support System for Tobacco Distribution Partition Optimization Based on Immune Co-Evolutionary Algorithm. Journal of Computers, Vol. 5, No. 3, March 2010. 